\title{
Peran Pelatihan dan Pengembangan Dalam Menciptakan Perilaku Kerja Yang Inovatif dan Efektifitas Organisasi
}

\author{
${ }^{1}$ Siti Rosmayati, ${ }^{2}$ Engkus Kuswarno, ${ }^{3}$ Achmad Mudrikah, ${ }^{4}$ Yosal Iriantara \\ ${ }^{1}$ Pascasarjana Institut Manajemen Koperasi Indonesia \\ ${ }^{2}$ Universitas Padjajaran \\ ${ }^{3,4}$ Universitas Islam Nusantara \\ siti.rosmayati91@gmail.com \\ koeskw@unpad.ac.id \\ achmadmudrikah@yahoo.co.id \\ yosaliriantara@uninus.ac.id
}

\begin{abstract}
Abstrak
Penelitian ini menggunakan penelitian kualitatif deskriptif dengan membuat model sederhana dalam pengembagan pelatihan untuk menciptakan kerja yang inovatif dan efektif di tempat kerja. Inovasi adalah pengembangan kerja sesuai keterampilan karyawan. Jika pikiran dan tindakan karyawan kreatif dan inovatif maka muncullah inovasi. Kebutuhan akan inovasi muncul ketika seseorang mencoba untuk melakukan pekerjaan kognitif yang tidak rutin. Belajar dan pengembangan sangat penting di antara berbagai praktik sumber daya pengembangan yang membantu karyawan untuk terus memperbarui pengetahuan, keterampilan, dan sikap yang diperlukan untuk inovasi. Penting bagi Organisasi untuk fokus pada memunculkan perilaku inovatif di antara karyawannya untuk memungkinkan inovasi. Pekerjaan tidak rutin membantu karyawan untuk menjadi inovatif dan memahami pentingnya menjadi inovatif dan mempelajari keterampilan yang merupakan prasyarat untuk perilaku inovatif. Pada model konseptual ini mencoba mengeksplorasi bagaimana pekerjaan tidak rutin dilakukan secara efektif melalui perilaku kerja yang inovatif.
\end{abstract}

Kata kunci: Perilaku Kerja Inovatif, Keterampilan Perilaku Inovatif.

\begin{abstract}
This research uses descriptive qualitative research by creating a simple model in the development of training to create innovative and effective work in the workplace. Innovation is the development of work according to the skills of its employees. If the thoughts and actions of employees are creative and innovative, then innovation emerges. The need for innovation arises when a person tries to do cognitive work that is not routine. Learning and development is very important among various development resource practices that help employees to continuously update the knowledge, skills and attitudes required for innovation. It is important for the Organization to focus on eliciting innovative behavior among its employees to enable innovation. Non-routine work helps employees to be innovative and understand the importance of being innovative and learn the skills that are prerequisites for innovative behavior. This conceptual model tries to explore how non-routine work is carried out effectively through innovative work behaviors.
\end{abstract}

Keywords: Innovative Work Behavior, Innovative Behavioral Skill.

\section{PENDAHULUAN}

Di antara berbagai disiplin ilmu manajemen, Manajemen Sumber Daya Manusia (SDM) memainkan peran utama dalam efektivitas organisasi mana pun. Manajemen Sumber Daya Manusia adalah proses yang dimulai dengan Rekrutmen dan diakhiri dengan Pensiun Karyawan. Ada banyak fungsi yang dilakukan oleh manajer sumber daya pengembangan yaitu, Rekrutmen,
Seleksi, Induksi Karyawan, memberikan orientasi, Memberikan Pelatihan dan Pengembangan, Penilaian Kinerja, Manajemen Kompensasi dan tunjangan, Motivasi Karyawan, menjaga hubungan manusia yang baik dan serikat pekerja mereka, memastikan karyawan langkah-langkah keselamatan, kesejahteraan dan kesehatan sesuai dengan undang-undang ketenagakerjaan. Di antara fungsi-fungsi di atas yang dilakukan oleh manajer sumber daya pengembangan, memberikan Pelatihan 
dan Pengembangan kepada Karyawan adalah salah satu fungsi utama Human Resource Management. Pelatihan \& Pengembangan memainkan peran penting dalam meningkatkan kinerja karyawan dan meningkatkan produktivitas sehingga menghasilkan efektivitas organisasi. Organisasi perlu mempertimbangkan biaya, waktu dan usaha yang terlibat dalam kegiatan Pelatihan \& Pengembangan sebagai investasi daripada biaya.

Dalam skenario kontemporer, organisasi ingin menampilkan diri di pasar, mereka ingin menjadi berbeda dan unik dari para pesaingnya dan untuk menarik pelanggan dengan produk dan layanan baru sebagai hasilnya organisasi akan memiliki keunggulan dibandingkan pesaingnya. Inovasi adalah konsepnya yang membuat setiap organisasi untuk berdiri terpisah dari kelompok. Inovasi membantu karyawan untuk meningkatkan produktivitas mereka melalui penciptaan dan penerapan proses inovatif dan membedakan organisasi melalui produk dan layanan yang inovatif. Pelatihan dan pengembangan adalah salah satu elemen penting yang membantu dalam membuat inovasi dan menciptakan perilaku inovatif di tempat kerja.

Pada penelitian Fadilah, (2018) Pelatihan dan pengembangan telah menjadi salah satu fungsi yang diperlukan di sebagian besar organisasi, karena mengarah pada kinerja tinggi di bidang yang sama dan merupakan bagian penting dari sumber daya manusia.

Penelitian yang dilakukan Florida Dessy Putri Sanuddin (2013) Organisasi yang ada harus menangani kebutuhan pelatihan yang terkait dengan perubahan dan pertumbuhan internasionalisasi industri, sudut pandang nasional yang beragam, dan tenaga kerja yang bervariasi.

Inovasi organisasi memiliki kecenderungan untuk meningkatkan kinerja organisasi dengan mengurangi biaya transaksi dan administrasi, meningkatkan kepuasan karyawan di tempat kerja, memperoleh akses ke aset yang tidak dapat diperdagangkan atau menurunkan biaya persediaan. Kepemimpinan, produktivitas karyawan, kerja tim, dan penyelarasan unit bisnis. Semua faktor yang digerakkan oleh manusia ini memainkan peran utama dalam kinerja dan efektivitas organisasi. Pendekatan sistematis adalah kunci keberhasilan perbaikan. Dengan kata lain, para ahli teori telah mendalilkan lima pendekatan untuk mengukur efektivitas organisasi- model tujuan, model sumber daya sistem, model proses, model multi konstituen dan pendekatan nilai-nilai yang bersaing.

Dalam mengadopsi teknologi digital yang cepat cenderung menguntungkan pekerja dengan keterampilan yang sulit digantikan dengan komputer, seperti kreativitas, keterampilan antarpribadi, atau kepemimpinan. Teknologi digital dapat meningkatkan produktivitas pekerja dalam pekerjaan ini dengan memungkinkan mereka untuk mengatur dan menerapkan ide atau keputusan mereka lebih cepat dan tepat. Jenis pekerjaan ini dianggap intensif dalam keterampilan non-rutin. Sebaliknya, pekerjaan yang lebih intensif dalam keterampilan rutin seperti akuntansi atau penyuntingan salinan, dan pekerjaan yang membutuhkan operasi manual berulang lebih rentan digantikan oleh teknologi baru. Misalnya, munculnya robot industri dan perangkat lunak yang dapat memproses pengembalian pajak atau mengoreksi dokumen akan membuat peran profesional tidak diperlukan dalam melaksanakan tugas-tugas ini. Pengembangan dan pelatihan ini harus tetap diperhatikan oleh organisasi karena sangat faktor sumber daya manusia tidak dapat digantikan oleh siapapun.

\section{TINJAUAN PUSTAKA}

\section{Pelatihan dan Pengembangan (Akuisisi pengetahuan dan keterampilan)}

Setiap tugas yang dilakukan oleh orang membutuhkan keterampilan dan pengetahuan terkini untuk melakukan tugas secara efektif dan efisien. Kapan tugas dan pekerjaan menjadi lebih kompleks dan rumit perlu adanya pelatihan dan pengembangan. Organisasi perlu memberikan Pelatihan \& Pengembangan kepada karyawan untuk bertahan dalam pekerjaan. Pelatihan adalah suatu proses yang membantu dalam mengembangkan Pengetahuan dan Keterampilan karyawan untuk memajukan dan mengubah kinerja mereka di tempat kerja. Pelatihan memberikan kesadaran tentang Informasi dasar yang dibutuhkan untuk melakukan pekerjaan tertentu, Pengetahuan untuk meningkatkan kinerja pada pekerjaan dan Keterampilan untuk menunjukkan kemampuan karyawan. Pelatihan dianggap efektif hanya jika mengatasi kesenjangan pengetahuan/keterampilan, mempersiapkan karyawan untuk masa depan dengan serangkaian keterampilan baru.

\section{Langkah-langkah untuk membangun Program Training yang Efektif:}

Sebuah perusahaan meningkatkan efektivitas dan kinerjanya dengan tenaga kerja terampil perusahaan. Jadi perusahaan fokus dan berinvestasi pada program Pelatihan \& Pengembangan yang efektif untuk efektivitas organisasi (Malau et al., 2019). Uang yang dikeluarkan untuk kegiatan Pelatihan \& Pengembangan dianggap sebagai investasi hanya ketika Pelatihan \& Pengembangan memenuhi tujuan peningkatan kinerja tenaga kerja yang dimaksudkan (Dessler, 2014). Agar program pelatihan menjadi efektif, Pelatihan \& 
Pengembangan harus dirancang dan dikembangkan secara efektif. Manajer berjuang dalam merancang program yang efektif seperti itu. Efektivitas Pelatihan \& Pengembangan tergantung pada perancangan dan penyampaian kegiatan pelatihan secara efektif dan juga pada metode Pelatihan \& Pengembangan (Sobirin, 2019). Pelatihan agar efektif, departemen Pelatihan \& Pengembangan pertama harus tahu mengapa pelatihan diperlukan pelatihan seperti apa dan bagaimana harus disampaikan kepada audiens. Hanya dengan begitu pelatihan bisa efektif. Langkah pertama untuk membuat program pelatihan menjadi efektif adalah dengan mengidentifikasi dan menganalisis kebutuhan pelatihan, yaitu training need assessment (TNA).

Kebutuhan tersebut dapat muncul pada tiga tingkatan a) pada tingkat organisasi, berdasarkan perencanaan strategis, kebutuhan bisnis dan tujuan serta sasaran organisasi, b) pada tingkat individu, berdasarkan tingkat kinerja karyawan, kebutuhan yang diperlukan keterampilan dan peningkatan pengetahuan, c) pada tingkat operasional, pekerjaan atau tugas yang akan diberikan kepada karyawan. Kebutuhan dapat diidentifikasi melalui penilaian kinerja, kesenjangan pengetahuan, kebutuhan pengembangan karyawan, kebutuhan manajer dan bisnis. Setiap program pelatihan yang sudah jadi tidak dapat digunakan untuk semua jenis kebutuhan karyawan atau organisasi. Itu harus ditawarkan berdasarkan kebutuhan (Darmayanti, 2014).

Pelatihan merupakan unsur penting bagi produktivitas dan kompetensi karyawan. Salah satu tanggung jawab utama suatu organisasi adalah menentukan kebutuhan nyata akan pelatihan (dapatkah masalah tersebut diatasi melalui pelatihan atau tidak). Penilaian kebutuhan pelatihan merupakan langkah penting dan awal dalam proses pelaksanaan dan penyediaan program pelatihan yang tepat. Metode untuk menganalisis atau menilai kebutuhan pelatihan dalam suatu organisasi adalah: Penilaian kinerja, Sasaran/Kebutuhan Bisnis, Penilaian Diri dan Salam Pribadi, Survei Kuesioner, Matriks Kompetensi, Indeks Kepuasan Klien/Pelanggan, Persyaratan Klien/Proyek, Tingkat Karyawan dan Analisis Kesenjangan, Wawancara Pribadi, Pengamatan Langsung, Umpan Balik Sejawat, Contoh Pekerjaan, Pekerjaan Lantai, Papan Dasbor dan bagan kesalahan, Umpan balik penilaian 360 derajat, Pengetahuan dan keterampilan yang dibutuhkan oleh tim (Prabandari \& Taviprawati, 2021). training need assessment (TNA) memiliki banyak manfaat bagi organisasi: a) mengidentifikasi dan mengatasi kebutuhan mendesak akan pelatihan b) membantu karyawan untuk lebih memahami peran pekerjaan dan tugas dan tanggung jawab mereka c) bertindak sebagai alat untuk pengembangan karyawan atau manajemen d) menciptakan iklim belajar yang kondusif (Latief, 2012). Semakin baik penilaian kebutuhan pelatihan maka semakin baik pula program pelatihan tersebut. Upaya pelatihan menjadi sia-sia ketika penilaian kebutuhan dilakukan dengan sia-sia. training need assessment (TNA) mengarah pada pengembangan program pelatihan yang akurat yang pada akhirnya mengarah pada peningkatan kinerja. Alasan penilaian kebutuhan adalah a) identifikasi area masalah dalam organisasi b) memenangkan dukungan manajemen c) data untuk mengukur efektivitas pelatihan d) analisis biaya-manfaat program pelatihan. training need assessment (TNA) berguna dalam mencapai tujuan organisasi dan menjembatani kesenjangan antara keterampilan yang ada dan keterampilan yang dibutuhkan karyawan untuk kinerja tinggi (Fadilah, 2018).

Kebutuhan pelatihan adalah untuk memperbarui karyawan dengan perkembangan teknologi terbaru. Belajar dikatakan sebagai proses yang tidak pernah berakhir; meskipun karyawan cukup baik untuk melakukan tugas, mereka masih membutuhkan pelatihan penyegaran (atau pelatihan ulang) dan untuk mengetahui tren terbaru. Kebutuhan akan perubahan dapat muncul dari lamanya masa kerja karyawan dalam organisasi (Sedarmayanti, 2017). Setelah kebutuhan pelatihan diketahui, kesenjangan kinerja diidentifikasi maka harus ditangani dengan tepat dan membuat strategi program, metode instruksi untuk program pelatihan yang efektif dan efisien yaitu merancang program yang sesuai dengan tren saat ini. Perancangan terutama memiliki tiga komponen yaitu: menyesuaikan hasil belajar dengan kurikulum, menguraikan hasil belajar, dan mendapatkan persetujuan dari manajemen. Ini membuat keputusan praktis yang meliputi strategi, metode penyampaian, struktur, durasi, penilaian, dan umpan balik. Ada beberapa metode penyampaian atau metode pelatihan yang digunakan secara luas di banyak organisasi, tetapi Rosmayati \& Maulana (2021) menyarankan bahwa tidak ada satu metode terbaik yang membuat pelatihan menjadi efektif. Pembelajaran berlangsung berdasarkan metode penyampaian campuran. Berdasarkan kebutuhan dan situasi, metode pelatihan yang berbeda digunakan. Mengikuti pelatihan yang dipimpin oleh instruktur sepenuhnya atau pelatihan berbasis komputer sepenuhnya tidak akan efektif. Pembelajaran terjadi ketika peserta pelatihan memiliki keterikatan psikologis dalam kegiatan pelatihan. Perusahaan yang menganggap pelatihan sebagai strategi untuk keunggulan kompetitif tidak berpikir bahwa metode pembelajaran jarak jauh sebagai metode yang efektif untuk memberikan pelatihan tetapi efektif 
hanya jika terintegrasi dengan metode pelatihan di tempat kerja lainnya. Sedarmayanti (2017) menyimpulkan berdasarkan survei penelitian tentang metode penyampaian pelatihan yang berbeda seperti kasus langsung, magang, dan program belajar mandiri, konferensi video, kaset video, konferensi komputer, instruksi satu-ke-satu, dll., Hampir di antara metode-metode pelatihan, studi kasus langsung dan magang dinilai tinggi oleh para pelatih perusahaan. Ketika pelatihan dilakukan dengan metode yang sesuai maka program Pelatihan \& Pengembangan akan efektif dan peningkatan kinerja karyawan dapat dicapai. Efektivitas pelatihan dapat diukur berdasarkan beberapa elemen seperti tujuan, biaya, waktu, lokasi, frekuensi pelatihan, kompetensi pelatih, metode yang sesuai dari program pelatihan, konten dan gaya penyampaiannya.

Tuntutan dan persyaratan tersebut menyebabkan terjadinya perubahan dalam pelatihan formal dan informal. Perubahan melibatkan perubahan dalam teknologi dan proses produksi, pengetahuan dan informasi mengarah pada perlunya pelatihan dalam organisasi dan niat dan motivasi karyawan untuk belajar. Seperti yang dijelaskan Latief (2012) bahwa desain bukanlah tampilannya tetapi cara kerjanya dalam merancang program pelatihan harus fokus pada cara kerjanya dalam menciptakan pengetahuan dan kemampuan di antara karyawan. Membuat program secara efektif membutuhkan materi pelatihan dan isi kursus. Kriteria untuk menetapkan isi dan materi pelatihan adalah: masalah kinerja organisasi yang solusi pelatihannya, spesifikasi tujuan organisasi, proses kerja, dan tingkat kinerja saat ini, rincian pengetahuan dan keahlian yang dibutuhkan dari UKM, Tujuan pembelajaran dan pembelajaran hasil, strategi dan kurikulum pelatihan.Materi pelatihan meliputi Flip chart dan spidol, Handout untuk peserta pelatihan, Alat bantu kerja, Plakat, Slide PowerPoint, Script untuk pelatih, Papan tulis dan spidol (Fory, 2016). Ketika sebuah desain dibuat, maka ia akan dieksekusi untuk mengetahui apakah itu berhasil dengan cara yang diinginkan atau tidak. Eksekusi merupakan tahapan dimana materi pelatihan dan materi penilaian diperkenalkan, terdiri dari dua jenis yaitu Implementasi Pilot dan Implementasi Final yang dilanjutkan dengan evaluasi formatif dan sumatif. Ketika konten diuji sepenuhnya maka itu tersedia untuk pelajar. Ketika desain dijalankan untuk pengujian maka harus dikontrol dan dievaluasi untuk mengetahui penyimpangan dan untuk mengambil tindakan korektif. Efektivitas pelatihan dapat dievaluasi dengan Model empat tingkat Kirkpatrick adalah:

1. Level-1: Reaksi- sejauh mana reaksi yang disukai peserta;

2. Level-2: Learning- sejauh mana perolehan KSA berdasarkan partisipasi karyawan dalam kegiatan pelatihan atau pembelajaran;

3. Level-3: Perilaku- tingkat penerapan KSA di tempat kerja;

4. Level-4: Hasil- tingkat hasil yang diharapkan muncul setelah berpartisipasi dalam proses pembelajaran (Kirpatrick, 2011).

Evaluasi, tahap terakhir yang mengikuti pelaksanaan (pelaksanaan), ada dua jenis: evaluasi formatif dan evaluasi sumatif. Setelah pelaksanaan percontohan, hasil yang diperoleh melalui evaluasi diumpankan kembali dan fasilitas dibuat untuk menyempurnakan kegiatan pelatihan, yang disebut sebagai evaluasi formatif. Setelah ini pergi ke tahap desain dan pengembangan untuk perubahan lebih lanjut. Akhirnya evaluasi akhir dilakukan setelah implementasi akhir konten dan materi yang disetel. Tahap terakhir yang mengikuti implementasi (pelaksanaan), ada dua jenis: evaluasi formatif dan evaluasi sumatif. Setelah pelaksanaan percontohan, hasil yang diperoleh melalui evaluasi diumpankan kembali dan fasilitas dibuat untuk menyempurnakan kegiatan pelatihan, yang disebut sebagai evaluasi formatif. Setelah ini pergi ke tahap desain dan pengembangan untuk perubahan lebih lanjut. Akhirnya evaluasi akhir dilakukan setelah implementasi akhir konten dan materi yang disetel. Tahap terakhir yang mengikuti implementasi (pelaksanaan), ada dua jenis: evaluasi formatif dan evaluasi sumatif. Setelah pelaksanaan percontohan, hasil yang diperoleh melalui evaluasi diumpankan kembali dan fasilitas dibuat untuk menyempurnakan kegiatan pelatihan, yang disebut sebagai evaluasi formatif. Setelah ini masuk ke tahap desain dan pengembangan untuk perubahan lebih lanjut. Akhirnya evaluasi akhir dilakukan setelah implementasi akhir konten dan materi yang disetel (Latief, 2012).

Transfer of Training (Penerapan Pengetahuan dan keterampilan). Apa pun yang dipelajari karyawan (pengetahuan, keterampilan, dan perubahan perilaku) dalam pelatihan harus diterapkan di tempat kerja. Ada

banyak faktor yang mempengaruhi transfer pelatihan, yaitu: desain tempat kerja, kesesuaian antara konten pelatihan dan kegiatan di tempat kerja, motivasi belajar, lingkungan yang menguntungkan untuk transfer \& relevansi 
pelatihan dengan kebutuhan peserta. Efektivitas pelatihan dan kinerja karyawan tergantung pada tingkat partisipasi karyawan dalam program Pelatihan dan Pengembangan. Oleh karena itu efektivitas pelatihan tidak hanya diukur melalui metode dan materi pelatihan yang tepat tetapi transfer pelatihan memainkan peran penting. Perolehan pengetahuan dan keterampilan dari kegiatan pelatihan dan Penerapan pengetahuan dan keterampilan di tempat kerja mengarah pada efektivitas pelatihan dan efisiensi karyawan.

\section{HASIL PENELITIAN}

Penelitian dan pengembangan didefinisikan sebagai suatu metode penelitian yang dipakai untuk menghasilkan suatu produk dan menguji efektivitas produk penelitian (Sugiyono, 2018). Pelatihan juga memiliki efek pada sikap karyawan yang pada gilirannya membuat mereka bekerja dengan baik
Pengembangan membantu dalam mengelola konflik antara majikan dan karyawan, antara karyawan dan karyawan. Dengan pelatihan yang efektif, aplikasi (transfer) teknis dan perilaku yang diperoleh keterampilan meningkatkan kinerja pekerjaan yang mengarah pada kepuasan kerja karyawan dan keterlibatan organisasi. Hanya mengembangkan pelatihan kerja akan membuat karyawan berkomitmen terhadap pekerjaannya. Pelatihan dan Pengembangan harus menciptakan Perilaku Inovatif dalam diri karyawan. Studi penelitian jelas bahwa pelatihan dan pengembangan memunculkan berbagai atribut karyawan yaitu. Perilaku kerja yang inovatif, komitmen afektif, kecakapan kerja, mengelola konflik yang pada akhirnya mengarah pada peningkatan kinerja dan produktivitas karyawan. Daftar atribut karyawan yang diperoleh melalui kegiatan Pelatihan ditunjukkan pada

\section{program pelatihan dan pengembangan yang efektif}

dengan kemahiran. Kegiatan Pelatihan dan
Atribut karyawan perilaku kerja inovatif komitmen afektif kemahiran kerja manajemen konflik pengetahuan, keterampilan dan sikap \& lain-lain

Gambar 1 Atribut karyawan yang diperoleh melalui Pelatihan dan Pengembangan yang efektif

\section{Kerangka Konseptual}

\section{Inovasi dan Perilaku Kerja Inovatif}

Dengan mempertimbangkan atribut di atas yang diperoleh melalui Pelatihan dan Pengembangan, penelitian ini menggambarkan pentingnya perilaku kerja yang inovatif di antara karyawan. Inovasi dan Perilaku Kerja Inovatif didefinisikan sebagai perilaku yang terkait dengan pembangkitan dan implementasi ide-ide baru dan kreatif. Inovasi adalah kata kunci dalam bisnis, organisasi harus mempunyai inovasi dalam mengembangkan karyawan nya. Pelatihan dan Pengembangan membantu karyawan dan organisasi untuk memiliki perilaku kerja yang inovatif. Tetapi perusahaan mengabaikan untuk menyediakan Pengembangan dan Pelatihan yang tepat di mana hanya berfokus pada alat dan proses, yang tidak cukup untuk menciptakan inovasi. Budaya berorientasi inovatif dapat diciptakan melalui Pelatihan dan. Seperti yang disarankan oleh Kirpatrick (2011). Pelatihan dan Pengembangan harus menciptakan perilaku kerja yang inovatif pada karyawan. Ketika struktur organisasi (tim) organik dan karyawan berorientasi pada tujuan memiliki dampak positif pada Inovasi dan Perilaku Kerja Inovatif. Pelatihan dan Pengembangan adalah salah satu praktik terbaik untuk mengembangkan Inovasi dan Perilaku Kerja
Inovatif pada karyawan. Perilaku inovatif karyawan dalam suatu organisasi dipengaruhi oleh kurangnya karyawan yang terampil secara teknologi, gaya kepemimpinan (terutama kepemimpinan transformasional) dan berbagi pengetahuan. Faktor penentu perilaku inovatif adalah kebahagiaan di tempat kerja dan dukungan rekan kerja, Motivasi (intrinsik dan ekstrinsik), Kepribadian proaktif, dukungan kepemimpinan dan lingkungan yang kondusif untuk inovasi, harapan peran manajerial, gaya pemecahan masalah, hubungan kelompok kerja. Perilaku kerja yang inovatif dapat dipengaruhi oleh pelatihan inovasi, kesempatan belajar yang efektif dan peran pekerjaan yang didesain ulang. Inovasi adalah salah satu kriteria yang membantu organisasi untuk menjadi berbeda di pasar dan memiliki keunggulan kompetitif, memenuhi harapan konsumen, menanggung tekanan kompetitif. Kreativitas dalam pelatihan teknik membantu organisasi untuk menciptakan inovasi pada karyawan yang pada akhirnya mengarah pada organisasi yang inovatif.

Pelatihan memainkan peran penting dalam kreativitas dan inovasi. Organisasi harus melakukan upaya untuk merancang dan mengembangkan intervensi pelatihan yang tepat. Sejalan dengan penelitian Fadilah, (2018) mengemukakan bahwa pengembangan sumber daya manusia, melalui 
Pelatihan dan Pengembangan, mempengaruhi inovasi organisasi dengan memberikan dampak positif pada keterlibatan karyawan, kepemimpinan, motivasi untuk belajar, mempromosikan budaya belajar dan mengembangkan modal sosial. Intervensi pelatihan terutama terkait soft skill (behavioral dan professional skill) dan technical skill berdampak positif terhadap Inovasi.

Untuk memperoleh Inovasi dan Perilaku Kerja Inovatif di antara karyawan, program pelatihan yang efektif harus fokus pada berbagai kegiatan yang melepaskan ketangkasan kreatif dan inovatif yang terbengkalai. Dengan demikian memungkinkan organisasi untuk memiliki keunggulan kompetitif dan untuk melakukan dengan cepat. Seperti disebutkan di atas penelitian kebutuhan pelatihan dilakukan pada tiga tingkatan; Pada tingkat tugas atau operasional, analisis kebutuhan menentukan jenis menentukan analisis kebutuhan yang dibutuhkan karyawan untuk melakukan pekerjaannya secara efektif dan efisien. Saat melakukan pekerjaan secara efektif, karyawan dapat dilatih untuk melakukan pekerjaan mereka secara inovatif. Tugas dapat dibagi menjadi tugas Rutin (manual dan kognitif) dan Non-rutin (manual dan kognitif). Studi konseptual ini mencoba untuk mengeksplorasi pentingnya perilaku inovatif dalam menyelesaikan pekerjaan yang begitu-begitu saja. Pekerjaan dapat dibagi lagi menjadi Analitis dan Interaktif (atau interpersonal).

Pekerjaan analitis meliputi analisis data atau informasi, pemikiran kreatif, interpretasi informasi untuk orang lain, Pekerjaan interaktif meliputi Manajemen hubungan (membangun dan memelihara hubungan), Kepemimpinan (membimbing, mengarahkan dan memotivasi bawahan, melatih dan mengembangkan orang lain). Keterampilan yang diperlukan untuk melakukan pekerjaan adalah penalaran abstrak, berpikir sistem, kolaborasi, dan kemampuan bereksperimen.

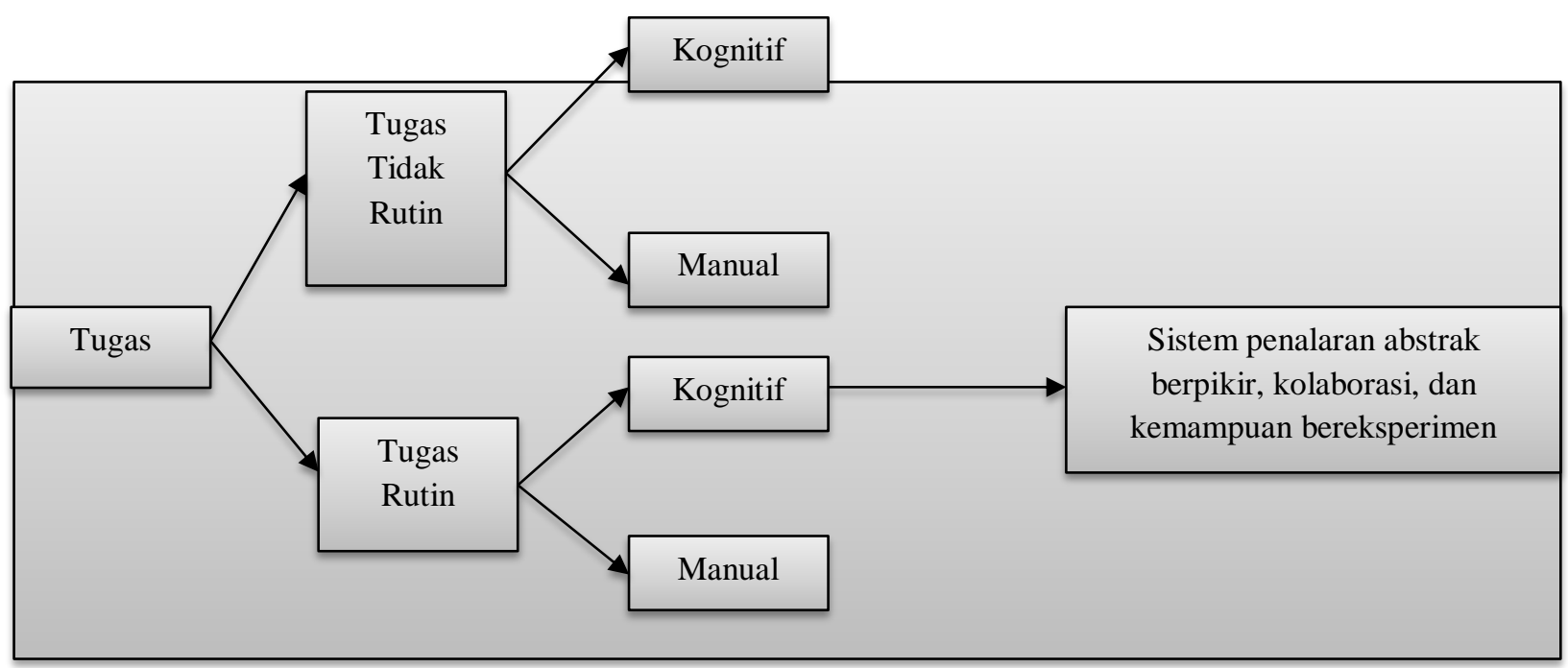

gambar 2 Jenis Tugas

Keterampilan yang diperlukan untuk menjadi inovatif di tempat kerja adalah berpikir divergen, rasa ingin tahu, bersemangat, berani, percaya diri, ingin tahu, kreatif, tantangan, fokus, kecerdasan emosional, komitmen, belajar dari kegagalan, pendengar yang baik, kualitas kepemimpinan, berjuang untuk keunggulan, pro- aktivitas \& ketekunan, kehati-hatian, dan modal sosial. Tugas tidak rutin adalah peristiwa atau aktivitas yang jarang terjadi oleh karena itu, rincian bahaya dan tindakan perlindungan mungkin tidak sepenuhnya dikembangkan atau diketahui oleh orang yang akan melakukan tugas tersebut. Karyawan yang memiliki perilaku kerja inovatif mengarah pada penyelesaian tugas tidak rutin secara efektif seperti gambar 3 di bawah ini.

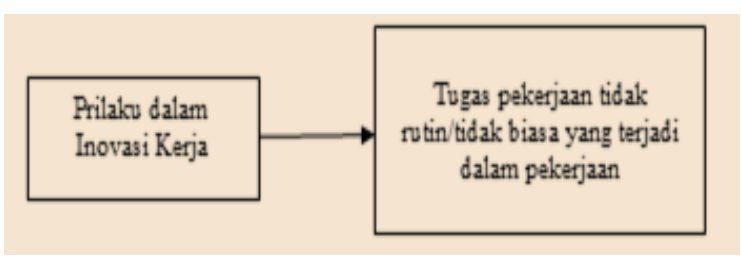

Gambar 3 Pekerjaan tidak rutin yang dilakukan oleh orang-orang yang berperilaku inovatif di tempat kerja

Meskipun ada pekerjaan tertentu yang dapat 
digantikan oleh mesin, pekerjaan tidak rutin sebagian besar dilakukan oleh orang-orang. Ketika karyawan dilatih dan dikembangkan secara efektif; ketika ada budaya untuk belajar adalah mungkin untuk melaksanakan pekerjaan tidak rutin secara efektif. Perilaku inovatif karyawan sangat penting bagi organisasi untuk menjadi pemimpin di pasar. Berdasarkan tinjauan pustaka di atas model dikonseptualisasikan seperti gambar 4 di bawah ini.

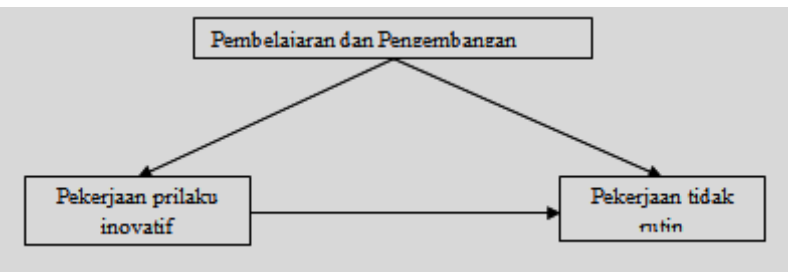

Gambar 4 Peran pembelajaran dan pengembangan dalam menyelesaikan tugas-tugas tidak rutin dengan menciptakan Inovasi dan Perilaku Kerja Inovatif di antara karyawan

Kebijakan pasar tenaga kerja dapat membantu melunakkan pukulan terhadap pekerja rutin saat perubahan teknologi bergulir. Sistem perlindungan sosial yang efisien dan tepat sasaran, mengurangi hambatan terhadap mobilitas pekerjaan dan memperkuat sistem pembelajaran seumur hidup dapat membantu melindungi pekerja yang dipindahkan dan membantu mereka menemukan pekerjaan baru selama kejutan teknologi yang akan datang dengan peran inovasi dalam mengembangkan pekerjaan termasuk keterampilan yang harus karyawan miliki.

\section{SIMPULAN DAN SARAN}

\section{Simpulan}

Terbukti bahwa Pelatihan dan Pengembangan memainkan peran penting dalam meningkatkan kinerja karyawan melalui penanaman perilaku kerja inovatif yang membantu dalam mencapai pekerjaan yang tidak rutin secara efektif dan inovatif. Tugas kerja tidak rutin adalah tugas-tugas yang karyawan tidak secara teratur melakukan atau melakukan untuk pertama kalinya. Karena tugas tidak dilakukan secara rutin, kemungkinan cedera dan/atau penyakit pada karyawan yang melakukan tugas. Dalam mengadopsi teknologi digital yang cepat cenderung menguntungkan pekerja dengan keterampilan yang sulit digantikan dengan komputer, seperti kreativitas,

keterampilan antarpribadi, atau kepemimpinan. Teknologi digital dapat meningkatkan produktivitas pekerja dalam pekerjaan ini dengan memungkinkan mereka untuk mengatur dan menerapkan ide atau keputusan mereka lebih cepat dan tepat. Jenis pekerjaan ini dianggap intensif dalam keterampilan non-rutin. Sebaliknya, pekerjaan yang lebih intensif dalam keterampilan rutin seperti akuntansi atau penyuntingan salinan, dan pekerjaan yang membutuhkan operasi manual berulang lebih rentan digantikan oleh teknologi baru. Misalnya, munculnya robot industri dan perangkat lunak yang dapat memproses pengembalian pajak atau mengoreksi dokumen akan membuat peran profesional tidak diperlukan dalam melaksanakan tugas-tugas ini. Pengembangan dan pelatihan ini harus tetap diperhatikan oleh organisasi karena sangat faktor sumber daya manusia tidak dapat digantikan oleh siapapun.

\section{Saran}

Mengubah rutinitas memang tidak mudah. Namun di zaman ketika teknologi menggantikan tugas yang semakin berulang, kebijakan tenaga kerja seperti saat ini dapat membantu pekerjaan dapat disempurnakan dengan keterampilan kerja yang karyawan bawa ke tempat kerja nya. Dengan demikian jika kemampuan pegawai dengan inovasi tinggi akan baik dengan bidang pekerjaan yang dijalankan, serta didukung pula dengan adanya pemberian pelatihan dan pengembangan yang baik pula yang diberikan kepada karyawan, maka senantiasa karyawan akan mampu memberikan hasil kerja yang optimal bagi suatu organisasi.

\section{DAFTAR PUSTAKA}

Darmayanti, N. P. (2014). Pengaruh kompetensi intelektual dan motivasi berprestasi terhadap kinerja Pegawai pada Perusahaan Daerah Air Minum ( PDAM ) di Kabupaten Gianyar. EJournal Bisma Universitas Pendidikan Ganesha, 2(1), 1-10.

Dessler. (2014). Manajemen sumber daya manusia.

Fadilah, F. (2018). Pengaruh Kompetensi Pegawai, Motivasi Kerja dan Kompensasi Yang Diberikan Terhadap Kinerja PPID di Pemerintah Kota Lubuklinggau.pdf.

Florida Dessy Putri Sanuddin, A. . R. W. (2013). PENGARUH KEPUASAN KERJA DAN MOTIVASI KERJA TERHADAP KINERJA KARYAWAN PT. SEMEN TONASA. Modus Journal, Vol 25, No.

Fory, N. (2016). Strategi Pengelolaan Pembelajaran.

Kirpatrick, J. (2011). Kirkpatrick empat tingkat Mitra Kirkpatrick.

Latief, B. (2012). Faktor-faktor yang 
Mempengaruhi Kinerja Karyawan PT Mega Mulia Servindo di Makassar. Jurnal Manajemen Dan Akuntansi, Volume 1, Nomor 2, Halaman 63.

Malau, A. G., Barasa, L., \& Sumali, B. (2019). Effect of Competence and Ship Crew Discipline on Performance Pt. Myclin Express Offshore. International Review of Management and Marketing, 9(5), 30-37. https://doi.org/10.32479/irmm.8530

Prabandari, W. D., \& Taviprawati, E. (2021). The Influence of Standard Operating Procedures on Employee Performance at Duta Laundry Tangerang. International Journal of Innovative Science and Research Technology, 6(6), 10001004.

Rosmayati, S., \& Maulana, A. (2021). Kepuasan Kerja Dan Motivasi Kerja Menjadi Variabel Prediktor Kinerja Karyawan. 1(1).

Sedarmayanti. (2017). Manajemen Sumber Daya Manusia.

Sobirin, A. (2019). Budaya Organisasi.

Sugiyono. (2018). Metode Penelitian Kuantitatif, Kualitatif, dan $R \& D$. 